\title{
Distribution and seasonal variation of picoplankton in Sanggou Bay, China
}

\author{
Li Zhao ${ }^{1,2}$, Yuan Zhao ${ }^{1,2, *}$, Jianhong $\mathrm{Xu}^{1,2}$, Wuchang Zhang ${ }^{1,2}$, Lingfeng Huang ${ }^{3}$, \\ Zengjie Jiang ${ }^{4,5}$, Jianguang Fang ${ }^{4,5}$, Tian Xiao ${ }^{1,2}$
}

${ }^{1}$ Key Laboratory of Marine Ecology and Environmental Sciences, Institute of Oceanology, Chinese Academy of Sciences, Qingdao 266071, PR China

${ }^{2}$ Laboratory of Marine Ecology and Environmental Science,

Qingdao National Laboratory for Marine Science and Technology, Qingdao 266071, PR China

${ }^{3}$ Key Laboratory of the Ministry of Education for Coastal and Wetland Ecosystem, Xiamen University, Xiamen 361102, PR China

${ }^{4}$ Key Laboratory of Sustainable Development of Marine Fisheries, Ministry of Agriculture, Yellow Sea Fisheries Research Institute, Chinese Academy of Fishery Sciences, Qingdao 266071, PR China

${ }^{5}$ Function Laboratory for Marine Fisheries Science and Food Production Processes,

Qingdao National Laboratory for Marine Science and Technology, Qingdao 266071, PR China

\begin{abstract}
Picoplankton abundance and biomass in Sanggou Bay, China, were investigated in 4 successive seasons (April, August and October 2011, January 2012). Different distribution patterns of picoplankton abundance and biomass were observed according to season and culture areas (bivalves or macroalgae). Synechococcus, picoeukaryotes and heterotrophic prokaryotes exhibited higher abundance and biomass in warm seasons (summer and autumn) than in cold seasons (spring and winter). Over all 4 seasons, picoplankton abundance was higher in the bivalve culture area than in the macroalgae culture area. Among picoplankton, picoeukaryotes contributed most to the carbon standing stock in summer and autumn. In spring and winter, the heterotrophic component biomass exceeded that of the autotrophic picoplankton. Picoeukaryotes were an important contributor $(21-27 \%)$ to total phytoplankton carbon biomass in spring to autumn. In spring, heterotrophic prokaryote biomass accounted for more than $56 \%$ of total phytoplankton biomass, and even exceeded phytoplankton biomass at some stations. As revealed by multiple stepwise regression analysis, physicochemical factors and protist grazing were the most important variables that controlled picoplankton distribution and variation. The reduction in grazing pressure, as well as phosphorus release by bivalves, is likely to explain the higher abundance of picoplankton in the bivalve culture area of Sanggou Bay.
\end{abstract}

KEY WORDS: Synechococcus · Picoeukaryotes · Heterotrophic prokaryotes · Sanggou Bay

\section{INTRODUCTION}

Marine picoplankton are generally defined as plankton in the size range $\leq 2 \mu \mathrm{m}$ in diameter. Picoplankton consist mostly of cyanoprokaryotes of the genera Synechococcus (SYN) (Johnson \& Sieburth 1979, Waterbury et al. 1979) and Prochlorococcus (Chisholm et al. 1988); picoeukaryotes (PEUK), a very diverse assemblage of eukaryotes; and hetero-

\footnotetext{
${ }^{*}$ Corresponding author: yuanzhao@qdio.ac.cn
}

trophic prokaryotes (HP). Picoplankton have a ubiquitous distribution and contribute significantly to phytoplankton biomass and primary production in the ocean (Agawin et al. 2000, Bell \& Kalff 2001). Picophytoplankton are major contributors to phytoplankton biomass in oligotrophic oceanic ecosystems (Li et al. 1983, Morán et al. 2004). SYN is present in inshore or coastal waters (Jochem 1988) and could account for $20 \%$ of the biomass of all living organ-

(C) The authors 2016. Open Access under Creative Commons by Attribution Licence. Use, distribution and reproduction are unrestricted. Authors and original publication must be credited. 
isms in the ocean (Caron et al. 1991). In some areas, PEUK are major biomass contributors (Worden et al. 2004). HP play a central role in the carbon flux in aquatic ecosystems. It is estimated that HP could consume $\sim 50 \%$ of primary production and be responsible for $10-20 \%$ of daily organic matter production (Ducklow \& Carlson 1992, Ducklow 2000).

The aquaculture of bivalves depends on the natural production of plankton. Suspension-feeding bivalves clear seston particles $>3 \mu \mathrm{m}$ in diameter from the water column (Newell 2004), and therefore adult bivalves cannot efficiently capture picoplankton. Although picoplankton do not directly contribute to the growth of bivalves, they can provide a large proportion of the food source for heterotrophic nanoflagellates and ciliates in the water column (Sherr \& Sherr 2002). By quantifying the ingestion of protists feeding on picoplankton, it is possible to determine how bivalves can use the microbial energy indirectly (Le Gall et al. 1997). Furthermore, some bivalve larvae can use picoplankton as part of their food source (Gallager et al. 1994), and therefore the study of picoplankton abundance and biomass is considered to provide useful information on the microbial food web in aquacultural regions such as Sanggou Bay.

Sanggou Bay is a semi-circular bay on the northeastern coast of China, with a large entrance towards the Yellow Sea in the east. Sanggou Bay has been used for aquaculture for $>20 \mathrm{yr}$ (Guo et al. 1999). Nearly $2 / 3$ of the area has been used for bivalves and seaweed aquaculture since 1983. The main cultivated species include the seaweed Laminaria japonica and longline culture of Chinese scallops Chlamys farreri and Pacific oysters Crassostrea gigas (Zhang et al. 2009). Although Sanggou Bay is one of the most important aquaculture areas for shellfish and seaweed in northern China, picoplankton distribution and seasonal variation, as well as their contribution to total phytoplankton biomass in Sanggou Bay, remain poorly documented. In the present study, we investigated picoplankton distribution over 4 successive seasons to gain insights into the factors and processes that regulate picoplankton abundance in Sanggou Bay.

\section{MATERIALS AND METHODS}

\section{Study area and sampling strategy}

Four cruises were conducted in Sanggou Bay (Fig. 1) over 4 successive seasons: April 2011 (spring), August 2011 (summer), October 2011 (autumn) and January 2012 (winter) using the fishing boat 'Lu Rong Yu Yang 65536'. The bivalve culture areas (collectively referred to as 'B-area' here) are located at the head of the bay, and the macroalgae culture areas ('M-area') are located at the mouth of Sanggou Bay (Lu et al. 2015a). During each cruise, seawater samples were collected from the sea surface (0.5 m depth) at 19 stations (Fig. 1) using a Ruttner sampler (HYDROBIOS). In situ parameters such as water temperature and salinity were determined with a YSI® Professional Plus series multiprobe water quality meter.

\section{Sample analysis}

Seawater samples $\left(5 \mathrm{~cm}^{3}\right)$ for picoplankton flow cytometry analysis were fixed with paraformaldehyde (final concentration $1 \%$ ) immediately after collection. After $15 \mathrm{~min}$ at room temperature, the samples were frozen in liquid nitrogen until analysis was carried out in the laboratory (Marie et al. 2000b).
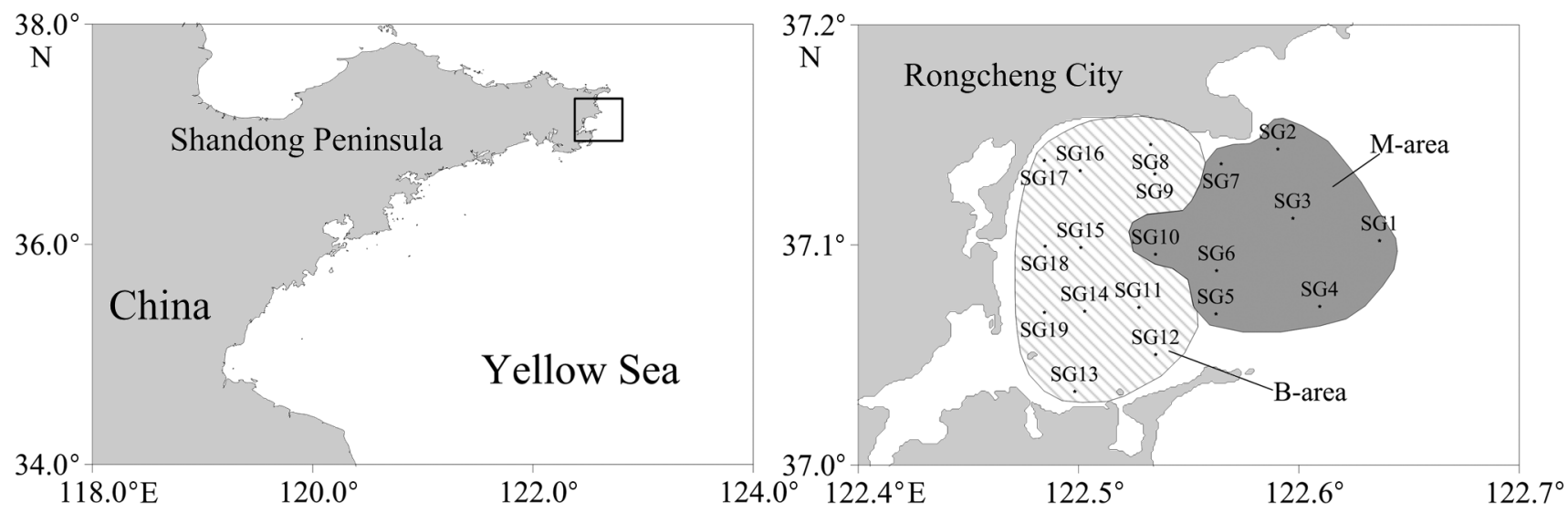

Fig. 1. Study area and location of sampling stations in Sanggou Bay, China. Grey area: macroalgae culture (M-area), dashed area: bivalve culture (B-area) 
Picoplankton flow cytometry analyses were run with a FACS Vantage SE flow cytometer (Becton Dickinson) equipped with a water-cooled Argon laser (488 nm, 1 W; Coherent). Protocols were adapted from the literature (Marie et al. 2000a,b). Fluorescent beads ( $2 \mu \mathrm{m}$; Polysciences; concentration unknown) were used as the internal standard for the instrument set-up and enumeration of picoplankton cells (Olson et al. 1993).

For SYN and PEUK analysis, forward scatter, side scatter and 2 fluorescence signals (red, range: $695 \pm$ $20 \mathrm{~nm}$; orange, range: $585 \pm 21 \mathrm{~nm}$ ) were recorded. Signals were triggered on red fluorescence to discard signals from heterotrophic organisms and inorganic particles. SYN and PEUK were distinguished on the basis of their scatter and fluorescence signals.

For HP analysis, seawater sub-samples were diluted 5-fold with TE buffer (Tris-EDTA, $100 \mathrm{mM}$ Tris-Cl, mM EDTA, pH 8.0; Sigma), and then stained with the nucleic acid dye SYBR Green I (Molecular Probes; final dilution $10^{-4}, \mathrm{v} / \mathrm{v}$ ) and kept in the dark at room temperature for $20 \mathrm{~min}$ before analysis. HP cell groups were resolved on the basis of their green (range: $530 \pm 15 \mathrm{~nm}$ ) fluorescence signal in the green fluorescence vs. sideward scatter cytogram.

For the determination of chlorophyll (chl) a concentration, 50-200 $\mathrm{cm}^{3}$ seawater samples were filtered onto GF/F glass-fibre filters (Whatman) under low vacuum. The filters were wrapped in aluminium foil and kept frozen at $-80^{\circ} \mathrm{C}$ until analysis in the laboratory. Chl a was extracted with $90 \%$ acetone at $4^{\circ} \mathrm{C}$ in the dark for $20 \mathrm{~h}$. Chl a concentrations were determined by the acidification method using a Turner Design (Model Trilogy 040) fluorometer, which was calibrated with pure chl a (Sigma) (Parsons et al. 1984).

Seawater samples for determining nutrient concentration were filtered through acid-washed, precleaned (with ultrapure water), $0.45 \mu \mathrm{m}$ pore-size acetate cellulose filters (Development Center of Water Treatment Technology, Hangzhou, PR China). The filtrates were poisoned by the addition of saturated $\mathrm{HgCl}_{2}$ (ca $1.5 \times 10^{-3} \mathrm{v} / \mathrm{v}$ ), preserved in low-density polyethylene bottles at room temperature and then analysed in the laboratory.

Nutrient concentrations including those of $\mathrm{NO}_{3}{ }^{-}$ and $\mathrm{NO}_{2}{ }^{-}$were determined spectrometrically using a SKALAR SAN plus autoanalyser, while $\mathrm{NH}_{4}{ }^{+}$and $\mathrm{PO}_{4}{ }^{3-}$ concentrations were determined by manual methods (Parsons et al. 1984). The concentration of dissolved inorganic nitrogen (DIN) was calculated as the sum of $\mathrm{NO}_{3}{ }^{-}, \mathrm{NO}_{2}{ }^{-}$and $\mathrm{NH}_{4}{ }^{+}$.

The enumeration of heterotrophic nanoflagellates (HNF) followed specifications by Lu et al. (2015a). The enumeration of ciliates was carried out according to
Yu et al. (2013). Picoplankton biomass was derived from the abundance of the cell groups resolved by flow cytometry. The abundance/biomass conversion factors used for SYN, PEUK and HP were $250 \mathrm{fg} \mathrm{C}^{\mathrm{C}} \mathrm{cell}^{-1}$ (Li et al. 1992), $1500 \mathrm{fg} \mathrm{C} \mathrm{cell}^{-1}$ (Zubkov et al. 1998) and $20 \mathrm{fg}$ C cell ${ }^{-1}$ (Lee \& Fuhrman 1987), respectively. Total phytoplankton biomass per unit volume was estimated from the chl a concentration assuming a constant C:chl a ratio of 50 (mg:mg) (Krempin \& Sullivan 1981).

Flow cytometry data were collected and analysed with CellQuest software (version 3.3, Becton Dickinson). Contour plots were generated using Surfer (version 8.0, Golden Software). Statistical analysis was conducted using SPSS (version 19, IBM SPSS Statistics). Two independent-sample $t$-tests were used to compare picoplankton abundance between the B- and M-areas. Spearman correlation analysis was used to detect significant relationships between variables. As an attempt to explain the variation in picoplankton distribution, stepwise multiple regression analysis was performed to assess the relative influence of potential factors controlling picoplankton abundance (temperature, salinity, nutrient and chl a concentrations and other biological components). The abundance data of picoplankton, HNF and ciliates used for statistical analysis were logtransformed to achieve homogeneity of the variance.

\section{RESULTS}

\section{Physicochemical conditions}

The seasonal distribution of seawater variables is shown in Fig. 2. The average surface water temperature of Sanggou Bay was 9.00, 21.36, 16.47 and $3.76^{\circ} \mathrm{C}$ in spring, summer, autumn and winter, respectively (Table 1). In spring and summer, water temperature decreased from inside Sanggou Bay to the open sea, while the opposite trend was observed in autumn and winter. Salinity increased from inside the bay to the open sea in summer, autumn and winter. Minimum average salinity was found in summer. In summer and autumn, high chl a concentrations were observed, especially at coastal stations inside the bay. Maximum chl a concentration reached $38.74 \mathrm{mg} \mathrm{m}^{-3}$ at Stn SG13 in summer. Average DIN varied from $4.83 \mu \mathrm{M}$ in summer to $10.44 \mu \mathrm{M}$ in autumn. The season-averaged $\mathrm{PO}_{4}{ }^{3-}$ concentration was much lower than that of DIN with a maximum $(0.11 \mu \mathrm{M})$ in spring and a minimum $(0.02 \mu \mathrm{M})$ in autumn and winter. At some stations in autumn and winter, $\mathrm{PO}_{4}{ }^{3-}$ concentration was below the detection limit (Fig. 2). 

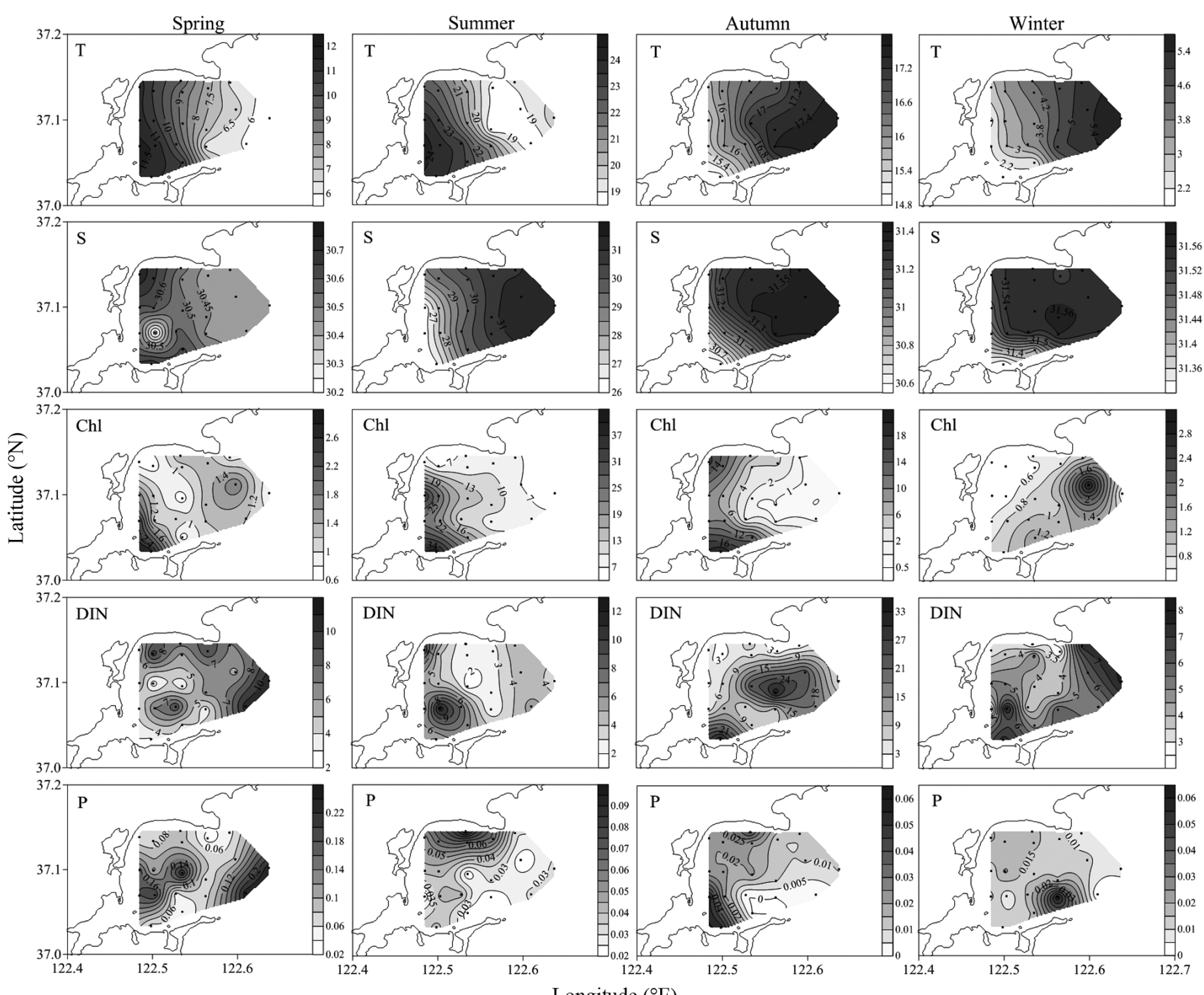

Longitude $\left({ }^{\circ} \mathrm{E}\right)$

Fig. 2. Spatial distribution of environmental variables in Sanggou Bay and adjacent area over 4 successive seasons. Black dots: sampling stations; T: temperature $\left({ }^{\circ} \mathrm{C}\right)$; S: salinity; Chl: chl a concentration $\left(\mathrm{mg} \mathrm{m}^{-3}\right)$; DIN: dissolved inorganic nitrogen (represents the sum of $\mathrm{NO}_{3}{ }^{-}, \mathrm{NO}_{2}{ }^{-}$and $\left.\mathrm{NH}_{4}{ }^{+}, \mu \mathrm{M}\right) ; \mathrm{P}: \mathrm{PO}_{4}{ }^{3-}(\mu \mathrm{M})$

\section{Distribution patterns of picoplankton abundance}

Depending on seasons, different distribution patterns of picoplankton abundances were observed in Sanggou Bay (Fig. 3). In spring, SYN abundance was lower at the centre of the bay than at other stations. In summer and autumn, SYN abundance decreased from coastal stations inside the bay to the open sea; however, the opposite trend was observed in winter. Average SYN abundance varied from $0.05 \times 10^{3}$ cells $\mathrm{cm}^{-3}$ in spring to $84.06 \times 10^{3}$ cells $\mathrm{cm}^{-3}$ in autumn, with a difference of about 4 orders of magnitude (Table 1). The season-averaged SYN abundance was significantly higher in summer and autumn than in spring and winter $(\mathrm{p}<0.01)$.

PEUK and HP had similar abundance distribution patterns in Sanggou Bay, with seasonal variation in the order winter $<$ spring $<$ autumn $<$ summer. Over all seasons, PEUK and HP abundances decreased from coastal stations inside the bay to the open sea. Both PEUK and HP abundances fluctuated less than that of SYN, with values from $1.80 \times 10^{3}$ cells cm$^{-3}$ and $3.00 \times$ $10^{5}$ cells cm$~^{-3}$ in winter to $82.57 \times 10^{3}$ cells cm${ }^{-3}$ and $40.77 \times 10^{5} \mathrm{cells} \mathrm{cm}^{-3}$ in summer, respectively (Table 1 ). The abundances of PEUK and HP were significantly higher in summer than in other seasons $(\mathrm{p}<0.01)$. 
Table 1. Summary of environmental factors, abundance and biomass of picoplankton in Sanggou Bay (SGB) and macroalgae and bivalve culture areas (M- and B-areas, respectively). DIN: dissolved inorganic nitrogen; SYN: Synechococcus; PEUK: picoeukaryotes; HP: heterotrophic prokaryotes. SYN C, PEUK C, HP C: carbon biomass of SYN, PEUK and HP, respectively. Diff.: Significant difference between values of $\mathrm{M}$ - and B-areas, ${ }^{*} \mathrm{p}<0.05,{ }^{* *} \mathrm{p}<0.01, t$-test; /: test was not performed; NS: not significant

\begin{tabular}{|c|c|c|c|c|c|c|c|c|}
\hline & \multicolumn{4}{|c|}{ Spring- } & \multicolumn{4}{|c|}{ - Summer } \\
\hline & SGB & M-area & B-area & Diff. & SGB & M-area & B-area & Diff \\
\hline Temperature $\left({ }^{\circ} \mathrm{C}\right)$ & $9.00 \pm 2.12$ & $6.82 \pm 1.06$ & $10.58 \pm 0.88$ & I & $21.36 \pm 2.02$ & $19.49 \pm 1.06$ & $22.73 \pm 1.30$ & I \\
\hline Salinity & $30.51 \pm 0.12$ & $30.44 \pm 0.04$ & $30.56 \pm 0.14$ & I & $29.39 \pm 1.78$ & $30.87 \pm 0.63$ & $28.31 \pm 1.55$ & I \\
\hline $\mathrm{Chl} a\left(\mathrm{mg} \mathrm{m}^{-3}\right)$ & $1.27 \pm 0.55$ & $1.15 \pm 0.35$ & $1.35 \pm 0.67$ & / & $14.41 \pm 9.74$ & $9.23 \pm 3.31$ & $18.18 \pm 11.23$ & I \\
\hline DIN $(\mu M)$ & $6.24 \pm 2.63$ & $7.00 \pm 2.92$ & $5.68 \pm 2.38$ & I & $4.83 \pm 2.69$ & $3.39 \pm 1.43$ & $5.87 \pm 2.96$ & I \\
\hline $\mathrm{PO}_{4}^{3-}(\mu \mathrm{M})$ & $0.11 \pm 0.07$ & $0.12 \pm 0.09$ & $0.10 \pm 0.06$ & / & $0.04 \pm 0.02$ & $0.03 \pm 0.01$ & $0.05 \pm 0.02$ & / \\
\hline SYN abund. $\left(10^{3}\right.$ cells cm $\left.{ }^{-3}\right)$ & $0.05 \pm 0.03$ & $0.06 \pm 0.03$ & $0.04 \pm 0.02$ & NS & $33.20 \pm 12.19$ & $27.08 \pm 5.45$ & $37.65 \pm 13.96$ & NS \\
\hline PEUK abund. $\left(10^{3}\right.$ cells $\left.\mathrm{cm}^{-3}\right)$ & $9.15 \pm 7.99$ & $1.49 \pm 1.15$ & $14.72 \pm 5.74$ & ** & $82.57 \pm 31.66$ & $77.71 \pm 16.70$ & $86.09 \pm 39.71$ & NS \\
\hline HP abund. $\left(10^{5}\right.$ cells cm$\left.{ }^{-3}\right)$ & $15.43 \pm 4.17$ & $11.61 \pm 3.58$ & $18.22 \pm 1.44$ & ** & $40.77 \pm 17.90$ & $24.54 \pm 9.05$ & $52.58 \pm 12.47$ & ** \\
\hline $\operatorname{SYN~C~}\left(\mathrm{mg} \mathrm{C} \mathrm{m}^{-3}\right)$ & $0.01 \pm 0.01$ & $0.01 \pm 0.01$ & $0.01 \pm 0.01$ & / & $8.27 \pm 3.04$ & $6.74 \pm 1.36$ & $9.37 \pm 3.48$ & / \\
\hline PEUK C $\left(\mathrm{mg} \mathrm{C} \mathrm{m}^{-3}\right)$ & $13.73 \pm 11.99$ & $2.24 \pm 1.72$ & $22.09 \pm 8.62$ & / & $123.85 \pm 47.49$ & $116.57 \pm 25.04$ & $129.14 \pm 59.56$ & I \\
\hline \multirow[t]{2}{*}{$\mathrm{HPC}\left(\mathrm{mg} \mathrm{C} \mathrm{m}^{-3}\right)$} & $30.87 \pm 8.34$ & $23.21 \pm 7.17$ & $36.43 \pm 2.88$ & I & $81.54 \pm 35.81$ & $49.08 \pm 18.10$ & $105.16 \pm 24.94$ & I \\
\hline & SGB & $\begin{array}{l}\text { Autumn- } \\
\text { M-area }\end{array}$ & B-area & Diff. & SGB & $\begin{array}{l}\text { Winter } \\
\text { M-area }\end{array}$ & B-area & Diff \\
\hline Temperature $\left({ }^{\circ} \mathrm{C}\right)$ & $16.47 \pm 0.79$ & $17.25 \pm 0.26$ & $15.91 \pm 0.49$ & / & $3.76 \pm 1.22$ & $4.89 \pm 0.66$ & $2.95 \pm 0.79$ & / \\
\hline Salinity & $31.18 \pm 0.23$ & $31.36 \pm 0.02$ & $31.06 \pm 0.23$ & 1 & $31.52 \pm 0.06$ & $31.55 \pm 0.01$ & $31.50 \pm 0.08$ & / \\
\hline $\mathrm{Chl} \mathrm{a}\left(\mathrm{mg} \mathrm{m}^{-3}\right)$ & $6.49 \pm 6.01$ & $1.38 \pm 1.21$ & $10.20 \pm 5.29$ & 1 & $0.90 \pm 0.55$ & $1.17 \pm 0.72$ & $0.71 \pm 0.30$ & / \\
\hline DIN $(\mu \mathrm{M})$ & $10.44 \pm 10.10$ & $13.90 \pm 11.72$ & $7.93 \pm 8.43$ & 1 & $4.88 \pm 1.72$ & $5.26 \pm 1.77$ & $4.61 \pm 1.70$ & / \\
\hline $\mathrm{PO}_{4}{ }^{3-}(\mu \mathrm{M})$ & $0.02 \pm 0.02$ & $0.01 \pm 0.01$ & $0.02 \pm 0.02$ & / & $0.02 \pm 0.01$ & $0.02 \pm 0.02$ & $0.02 \pm 0.00$ & I \\
\hline SYN abund. $\left(10^{3}\right.$ cells cm$\left.{ }^{-3}\right)$ & $84.06 \pm 80.74$ & $11.04 \pm 11.85$ & $137.16 \pm 65.34$ & $44^{* *}$ & $0.51 \pm 0.20$ & $0.62 \pm 0.07$ & $0.42 \pm 0.22$ & * \\
\hline PEUK abund. $\left(10^{3}\right.$ cells $\left.\mathrm{cm}^{-3}\right)$ & $57.42 \pm 66.40$ & $8.75 \pm 12.88$ & $92.82 \pm 67.42$ & $2^{* *}$ & $1.80 \pm 1.45$ & $1.34 \pm 0.49$ & $2.14 \pm 1.82$ & NS \\
\hline HP abund. $\left(10^{5}\right.$ cells cm $\left.{ }^{-3}\right)$ & $23.35 \pm 17.26$ & $8.22 \pm 3.24$ & $34.36 \pm 14.58$ & 8 ** & $3.00 \pm 0.62$ & $2.66 \pm 0.46$ & $3.25 \pm 0.61$ & NS \\
\hline $\operatorname{SYN~C~}\left(\mathrm{mg} \mathrm{C} \mathrm{m}^{-3}\right)$ & $21.01 \pm 20.19$ & $2.76 \pm 2.96$ & $34.29 \pm 16.34$ & $4 /$ & $0.13 \pm 0.05$ & $0.16 \pm 0.02$ & $0.10 \pm 0.06$ & l \\
\hline PEUK C $\left(\mathrm{mg} \mathrm{C} \mathrm{m}^{-3}\right)$ & $86.13 \pm 99.60$ & $13.12 \pm 19.32$ & $139.23 \pm 101.13$ & $13 /$ & $2.70 \pm 2.17$ & $2.01 \pm 0.73$ & $3.21 \pm 2.73$ & / \\
\hline $\mathrm{HP} \mathrm{C}\left(\mathrm{mg} \mathrm{C} \mathrm{m}^{-3}\right)$ & $46.71 \pm 34.53$ & $16.43 \pm 6.49$ & $68.72 \pm 29.15$ & $5 /$ & $6.00 \pm 1.23$ & $5.32 \pm 0.92$ & $6.50 \pm 1.23$ & / \\
\hline
\end{tabular}

The relationships between picoplankton abundance and environmental and biological factors were complex. In spring, PEUK and HP abundances were positively correlated with each other (Table 2). Both PEUK and HP abundances were positively correlated with water temperature, salinity and ciliate abundance. No significant correlation was found between SYN abundance and the other parameters. In summer, SYN abundance was positively correlated with PEUK and negatively correlated with salinity. HP abundance was positively correlated with HNF abundance, temperature and DIN, and negatively correlated with salinity. The abundances of all 3 picoplankton groups were positively correlated with chl a concentration. In autumn, SYN, PEUK and HP abundances were positively correlated with each other, as well as with HNF and ciliate abundances, and chl $a$ and $\mathrm{PO}_{4}{ }^{3-}$ concentrations, while they were negatively correlated with temperature and salinity. In winter, no significant correlation was found between picoplankton groups. SYN abundance was positively correlated with tem- perature and chl $a$ and negatively correlated with HNF and ciliate abundances. PEUK abundance was positively correlated with chl a concentration. HP abundance was negatively correlated with $\mathrm{chl}$ a concentration.

\section{Distribution of picoplankton in different aquaculture areas}

In warm seasons (summer and autumn), there was an obvious freshwater input to the bay (Fig. 2). All picoplankton groups exhibited higher abundances in the B-area than in the $\mathrm{M}$-area, especially in autumn (Fig. 3, Table 1). In cold seasons (winter and spring), SYN abundance remained low throughout Sanggou Bay, with slightly higher values in the M-area (Fig. 3, Table 1). For PEUK and HP, the abundances were still higher in the B-area, but the difference was not significant in winter.

As revealed by multiple stepwise regression analysis, warm-season grazing by protists was the most 


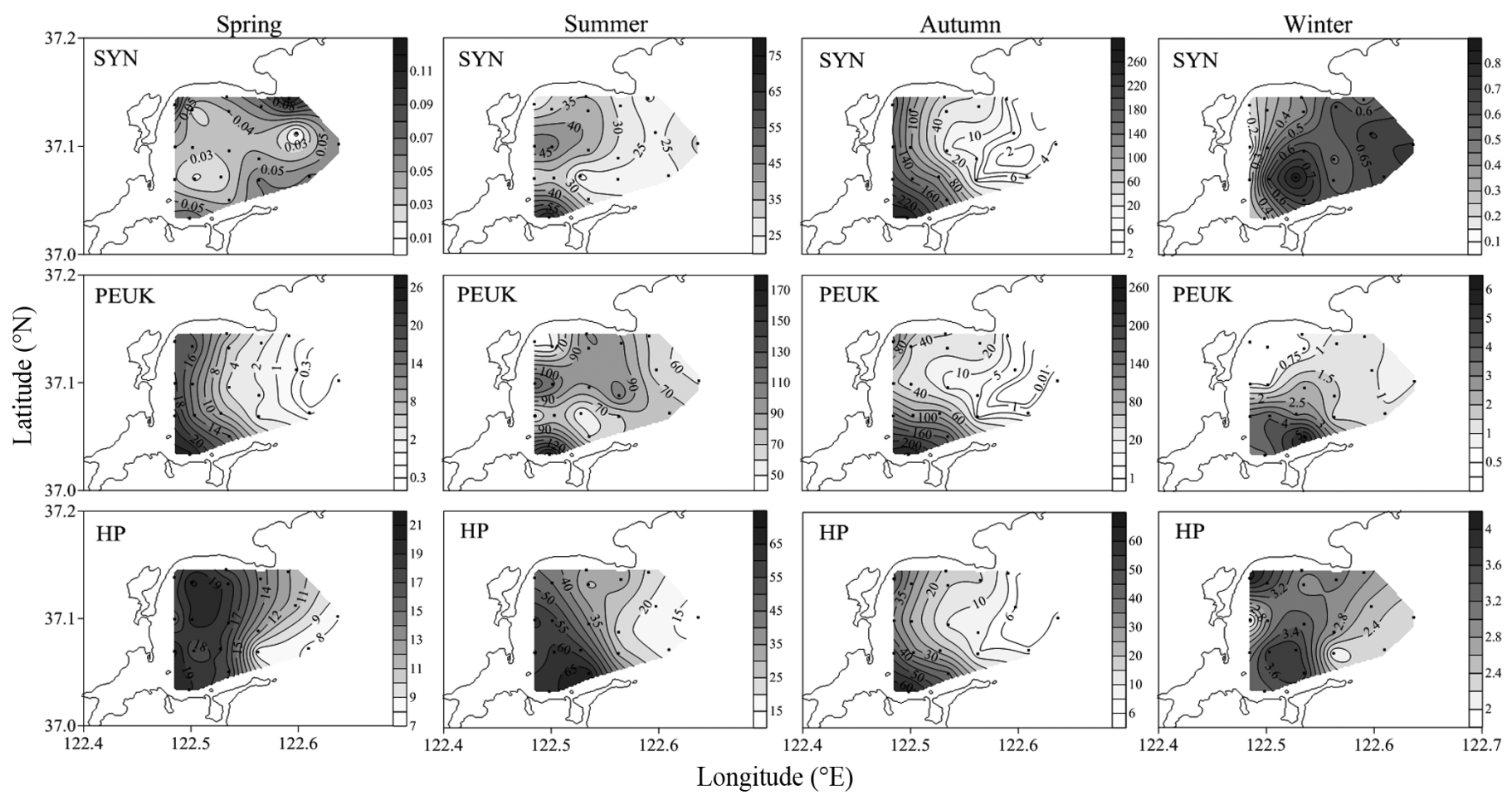

Fig. 3. Spatial distribution of picoplankton abundance in Sanggou Bay and adjacent area over 4 successive seasons. Synechococcus (SYN) and picoeukaryotes (PEUK): $\times 10^{3}$ cells cm${ }^{-3}$; heterotrophic prokaryotes (HP): $\times 10^{5} \mathrm{cells}^{-3}$

Table 2. Spearman's rank correlation coefficient between biological factors and picoplankton abundances in Sanggou Bay over 4 successive seasons (all n = 19). SYN: Synechococcus; PEUK: picoeukaryotes; HP: heterotrophic prokaryotes; HNF: heterotrophic nanoflagellates; T: temperature, S: salinity; DIN: dissolved inorganic nitrogen. Picoplankton, HNF and ciliate abundances were log transformed prior to analysis. Only correlations that were significant at the ${ }^{* *} 0.01$ level (2-tailed) and *0.05 level (2-tailed) are shown

\begin{tabular}{|c|c|c|c|c|c|c|c|c|c|c|c|}
\hline & & Log SYN & Log PEUK & Log HP & Log HNF & Log ciliates & $\mathrm{T}$ & $\mathrm{S}$ & Chl a & DIN & $\mathrm{PO}_{4}^{3-}$ \\
\hline Spring & $\begin{array}{l}\text { Log SYN } \\
\text { Log PEUK } \\
\text { Log HP }\end{array}$ & & & $0.786^{* *}$ & & $\begin{array}{l}0.774^{* *} \\
0.714^{* *}\end{array}$ & $\begin{array}{l}0.933^{* *} \\
0.765^{* *}\end{array}$ & $\begin{array}{l}0.743^{* *} \\
0.645^{* *}\end{array}$ & & & \\
\hline Summer & $\begin{array}{l}\text { Log SYN } \\
\text { Log PEUK } \\
\text { Log HP }\end{array}$ & & $0.604^{* *}$ & & $0.705^{* *}$ & & $0.861^{* *}$ & $\begin{array}{l}-0.553^{*} \\
-0.865^{* *}\end{array}$ & $\begin{array}{c}0.512^{*} \\
0.515^{*} \\
0.773^{* *}\end{array}$ & $0.470^{*}$ & \\
\hline Autumn & $\begin{array}{l}\text { Log SYN } \\
\text { Log PEUK } \\
\text { Log HP }\end{array}$ & & $0.961^{* *}$ & $\begin{array}{l}0.978^{* *} \\
0.960^{* *}\end{array}$ & $\begin{array}{l}0.955^{* *} \\
0.933^{* *} \\
0.960^{* *}\end{array}$ & $\begin{array}{l}0.899^{* *} \\
0.828^{* *} \\
0.870^{* *}\end{array}$ & $\begin{array}{l}-0.961^{* *} \\
-0.899^{* *} \\
-0.951^{* *}\end{array}$ & $\begin{array}{l}-0.964^{* *} \\
-0.946^{* *} \\
-0.948^{* *}\end{array}$ & $\begin{array}{l}0.928^{* *} \\
0.925^{* *} \\
0.953^{* *}\end{array}$ & & $\begin{array}{c}0.586^{* *} \\
0.496^{*} \\
0.581^{* *}\end{array}$ \\
\hline Winter & $\begin{array}{l}\text { Log SYN } \\
\text { Log PEUK } \\
\text { Log HP }\end{array}$ & & & & $-0.522^{*}$ & $-0.671^{* *}$ & $\begin{array}{l}0.608^{* *} \\
-0.471^{*}\end{array}$ & & $\begin{array}{l}0.730^{* *} \\
0.607^{* *}\end{array}$ & & \\
\hline
\end{tabular}

important variable that controlled picoplankton abundance and distribution in the M-area (Table 3). HNF abundance explained 66.5 and $80.8 \%$ of the variance for SYN and PEUK, respectively. For HP, chl a was the most important variable; however, HNF and ciliate abundance also explained about $8.3 \%$ of the abundance and distribution of HP. In the B-area, during warm seasons, physicochemical factors and HNF provided the best explanation for SYN and HP distribution, respectively. No significant variable was found for PEUK. In cold seasons, salinity was the most important variable controlling the distribution of picoplankton in both $\mathrm{M}$ - and Bareas (Table 3). 
Table 3. Summary of multiple stepwise regression analysis between picoplankton abundances and environmental and biological variables in culture areas of Sanggou Bay and adjacent area (M-area: macroalgae culture, B-area: bivalve culture; see Fig. 1) in warm (summer, autumn) and cold (winter, spring) seasons. Picoplankton, heterotrophic nanoflagellate (HNF) and ciliate abundances were $\log$ transformed prior to analysis. $\mathrm{R}^{2}$ : correlation coefficient of multiple determination. $\mathrm{R}^{2}$ change: change in multiple $\mathrm{R}^{2}$ caused by entering a new variable in a single step (hierarchical analysis). Results of $F>1$ and $\mathrm{p}<0.05$ represent improvements due to fitting the regression model is much greater than the inaccuracy within the model, which means the final model significantly improved our ability to predict the outcome variable. NS: not significant. SYN: Synechococcus; PEUK: picoeukaryotes; HP: heterotrophic prokaryotes; Chl: chl a concentration; T: temperature; S: salinity

\begin{tabular}{|c|c|c|c|c|c|c|c|c|}
\hline & & $\begin{array}{l}\text { Dependent } \\
\text { variables }\end{array}$ & $\begin{array}{l}\text { Variables } \\
\text { entered }\end{array}$ & $\mathrm{R}^{2}$ & $\begin{array}{c}\mathrm{R}^{2} \\
\text { change }\end{array}$ & Beta & $F$ & $\mathrm{p}$ \\
\hline \multirow[t]{9}{*}{ M-area } & \multirow{5}{*}{$\begin{array}{l}\text { Warm } \\
\text { seasons }\end{array}$} & Log SYN & Log HNF & 0.665 & 0.665 & 0.815 & 27.770 & $<0.001$ \\
\hline & & Log PEUK & Log HNF & 0.808 & 0.808 & 0.899 & 58.771 & $<0.001$ \\
\hline & & Log HP & Chl & 0.847 & 0.847 & 0.425 & 77.655 & $<0.001$ \\
\hline & & & Log HNF & 0.902 & 0.055 & 0.403 & 59.884 & $<0.001$ \\
\hline & & & Log ciliates & 0.930 & 0.028 & 0.240 & 53.098 & $<0.001$ \\
\hline & \multirow{4}{*}{$\begin{array}{l}\text { Cold } \\
\text { seasons }\end{array}$} & Log SYN & $\mathrm{S}$ & 0.813 & 0.813 & 0.901 & 52.011 & $<0.001$ \\
\hline & & Log PEUK & Log ciliates & 0.342 & 0.342 & 0.585 & 6.236 & $<0.001$ \\
\hline & & Log HP & $\mathrm{S}$ & 0.900 & 0.900 & -0.925 & 108.293 & $<0.001$ \\
\hline & & & Log ciliates & 0.942 & 0.042 & 0.207 & 89.943 & $<0.001$ \\
\hline \multirow[t]{9}{*}{ B-area } & \multirow{4}{*}{$\begin{array}{l}\text { Warm } \\
\text { seasons }\end{array}$} & Log SYN & $\mathrm{T}$ & 0.625 & 0.625 & -1.594 & 33.384 & $<0.001$ \\
\hline & & & $\mathrm{S}$ & 0.817 & 0.192 & -0.914 & 42.381 & $<0.001$ \\
\hline & & Log PEUK & & NS & NS & NS & NS & NS \\
\hline & & Log HP & Log HNF & 0.658 & 0.658 & 0.811 & 38.489 & $<0.001$ \\
\hline & \multirow{5}{*}{$\begin{array}{l}\text { Cold } \\
\text { seasons }\end{array}$} & Log SYN & $\mathrm{S}$ & 0.822 & 0.822 & 0.610 & 83.235 & $<0.001$ \\
\hline & & & Log HNF & 0.873 & 0.051 & -0.373 & 58.687 & $<0.001$ \\
\hline & & Log PEUK & $\mathrm{S}$ & 0.710 & 0.170 & -0.842 & 43.988 & $<0.001$ \\
\hline & & Log HP & $\mathrm{S}$ & 0.941 & 0.941 & -0.527 & 287.344 & $<0.001$ \\
\hline & & & $\mathrm{T}$ & 0.967 & 0.026 & 0.472 & 251.419 & $<0.001$ \\
\hline
\end{tabular}
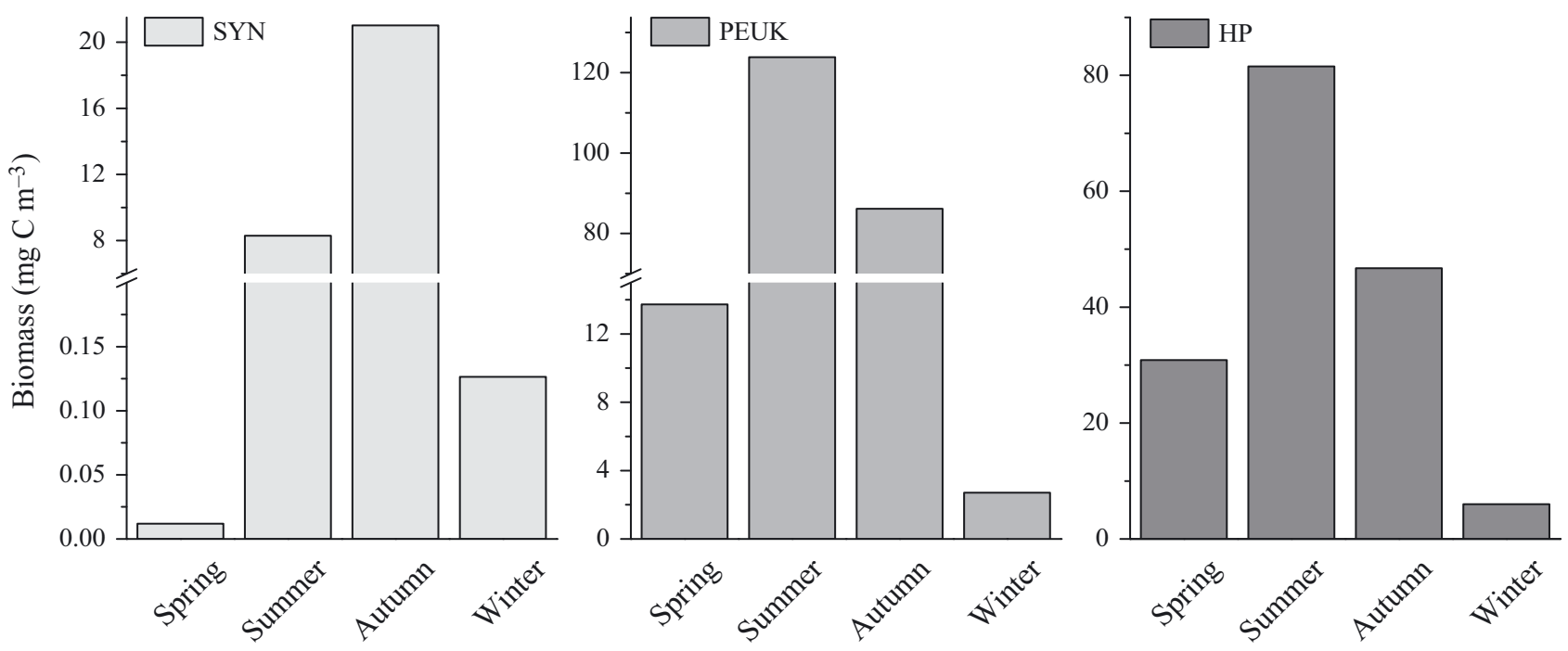

Fig. 4. Depth-averaged biomass $\left(\mathrm{mg} \mathrm{C} \mathrm{m}^{-3}\right)$ of picoplankton in Sanggou Bay over 4 successive seasons. SYN: Synechococcus; PEUK: picoeukaryotes; HP: heterotrophic prokaryotes. Note different $y$-axis scales

\section{Carbon biomass contribution of picoplankton to phytoplankton}

Among picoplankton, PEUK represented the highest standing stock of carbon biomass in summer and autumn (Fig. 4), contributing to $>50 \%$ of picoplankton biomass (Fig. 5). In spring and winter, the heterotrophic component of biomass exceeded that of autotrophic picoplankton. HP was the major contributor to picoplankton biomass in spring and winter. SYN biomass was relatively low compared with that of PEUK and HP throughout the 4 successive seasons (Fig. 4). 


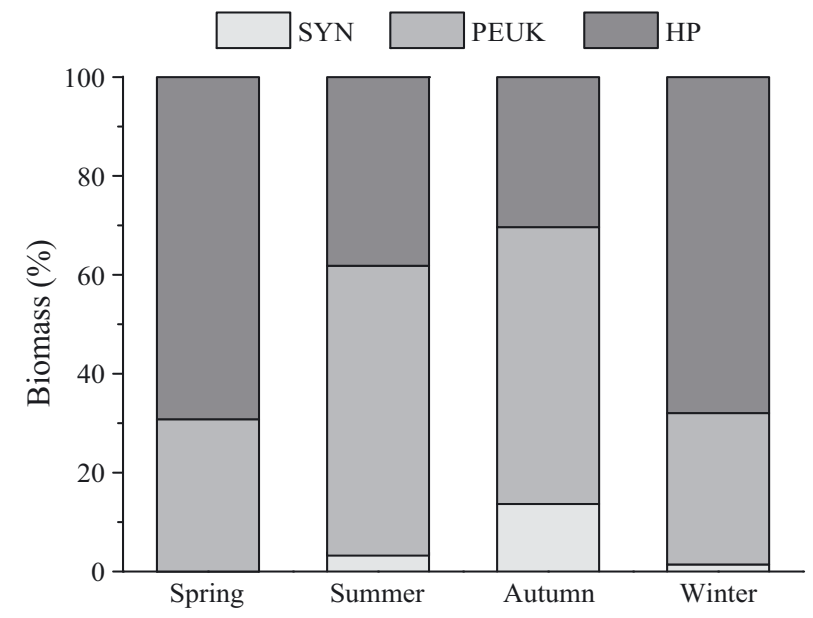

Fig. 5. Biomass contribution of Synechococcus (SYN), picoeukaryotes (PEUK) and heterotrophic prokaryotes (HP) to picoplankton biomass in Sanggou Bay over 4 successive seasons

In spring, summer and autumn, PEUK was an important (21.46-27.74\%) carbon contributor to total phytoplankton biomass (Fig. 6). This contribution decreased to $6.39 \%$ in winter. HP biomass amounted to $>50 \%$ of total phytoplankton biomass in spring, and at some stations even exceeded phytoplankton biomass. SYN contributed $6.82 \%$ to phytoplankton biomass in autumn and $<1.5 \%$ in other seasons.

\section{DISCUSSION}

\section{Picoplankton seasonal distribution and variation}

This is the first report on picoplankton abundance distribution and its seasonal variation in Sanggou Bay, China, with results comparable to those reported from other coastal waters (Vaquer et al. 1996, Kamiyama 2004, Bec et al. 2005, Kamiyama et al. 2009, Thomas et al. 2010, Bouvy et al. 2012). Picoplankton abundance distribution and its variations depend on both abiotic and biotic factors. Abiotic factors, also called bottom-up controls, include water temperature and salinity, as well as light and nutrient availability. The biotic factors (top-down controls) are essentially predation by nano- and micro-zooplankton, and lysis by virioplankton.

Picoplankton abundance is particularly affected by water temperature and nutrient availability (Agawin et al. 2000). Seasonal variation of SYN and HP abundances in temperate waters usually follows patterns with maxima in summer and minima in winter (Li 1998). In Sanggou Bay, a clear seasonality for picoplankton abundance and biomass was observed, associated with physicochemical features. High abundances and biomasses of SYN, PEUK and HP were found during summer and autumn, in agreement with previous reports (Vaquer et al. 1996, DuRand et al. 2001, Bec et al. 2005). SYN abundance is about 4 orders of magnitude higher in
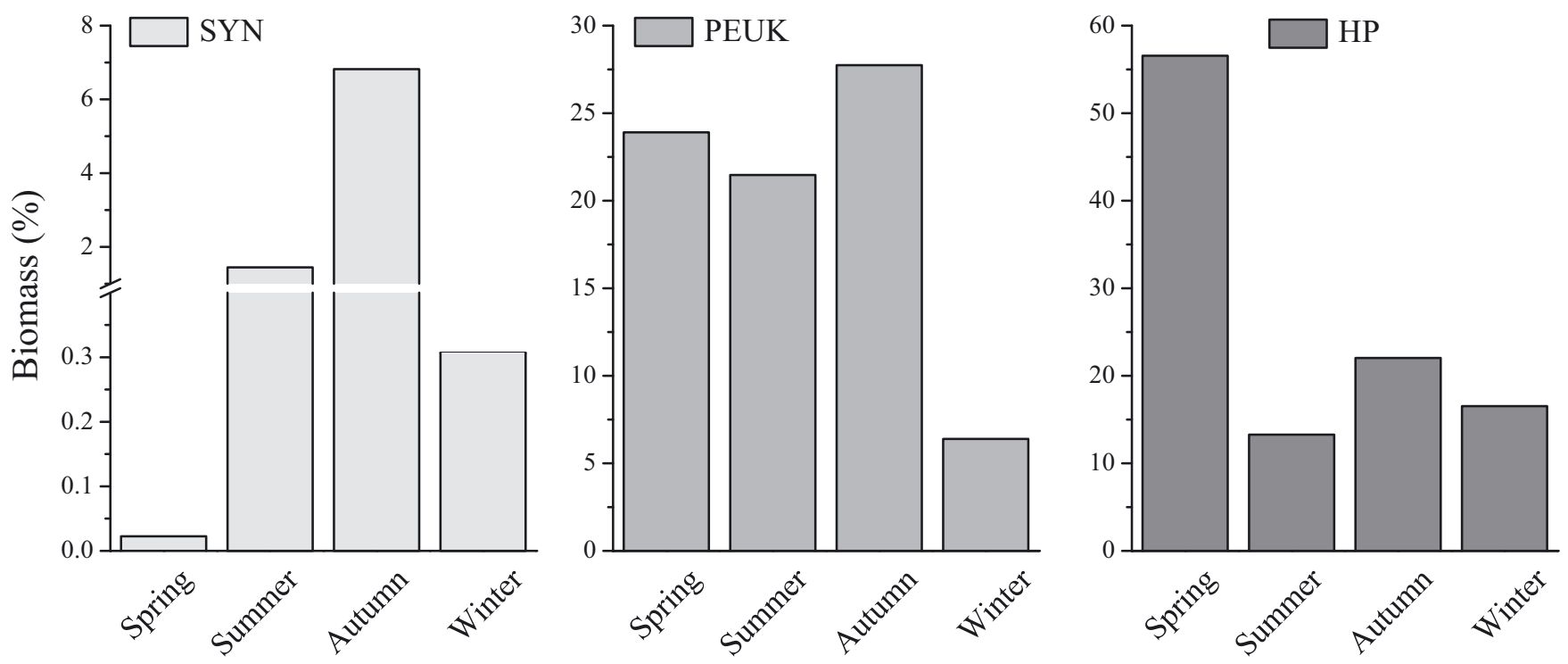

Fig. 6. Biomass contribution of Synechococcus (SYN), picoeukaryotes (PEUK) and heterotrophic prokaryotes (HP) to total phytoplankton biomass in Sanggou Bay over 4 successive seasons. The total phytoplankton biomass was derived from chlorophyll a concentration. Note different $y$-axis scales 
autumn than in spring in Sanggou Bay. Similar SYN variation was also found in previous studies (DuRand et al. 2001, Li \& Dickie 2001, Agawin et al. 2003). A 10 yr monthly observation (2006-2015) in Jiaozhou Bay, China, at a similar longitude and latitude, has revealed the same variation (T. Xiao, L. Zhao unpubl. data).

\section{Picoplankton in the aquaculture area}

Being an important component of the aquatic food web, picoplankton feed larger zooplankton that channel their carbon biomass from microbial to higher trophic levels (Azam et al. 1983). The aquaculture of bivalves depends on the production of natural plankton. Picoplankton $(<2 \mu \mathrm{m})$ are too small to be efficiently retained by most bivalves, including the scallop Chlamys farreri and oyster Crassostrea gigas (Barillé et al. 1993, Kreeger \& Newell 1996, Hawkins et al. 2001). However, the distribution of picoplankton is still affected by bivalves in aquaculture areas. Although picoplankton do not directly contribute to the growth of bivalves, they can provide a large proportion of the food source for HNF and ciliates in the water column (Sherr \& Sherr 2002). Most HNF $(2-20 \mu \mathrm{m})$ and ciliates (mostly $>10 \mu \mathrm{m})$ are much larger and can be efficiently captured by most bivalves (Riisgård 1988, Fournier et al. 2012). Therefore, bivalves can use the microbial energy indirectly (Le Gall et al. 1997). Nano- and micro-zooplankton grazing are important top-down control factors for picoplankton (Sherr \& Sherr 2002). Protists are recognized as the main consumers of SYN, PEUK and HP in similar environments (Kamiyama 2004, Bec et al. 2005). In the macroalgae culture area of Sanggou Bay, grazing by protists was the most important variable controlling picoplankton abundances and distribution in both warm and cold seasons. However, no such correlation could be observed in the bivalve culture area. Physicochemical factors such as temperature and salinity were the main control factors of picoplankton distribution. It is possible that HNF and ciliates in the B-area were efficiently retained by bivalves, alleviating grazing pressure on picoplankton and enabling a significantly higher abundance of picoplankton in this area, especially in warm seasons. We found possible collinearity between some variables used in the stepwise regressions (Table 3). It is possible that the estimates of the multiple regressions may change erratically in response to small changes in the data. To remedy the analysis, data were log transformed prior to analysis to standardize the variables in our study. Despite its shortcomings, stepwise regression has nevertheless been a suitable method used to predict influential factors in other research (e.g. Kimmel et al. 2012, Oberbeckmann et al. 2012).

A predominance of picoplankton has also been reported in other areas of intense bivalve farming (Dupuy et al. 2000). Traditionally, picophytoplankton has been viewed as having a critical growth dependence on inorganic nutrients. At low nutrient concentrations, picoplankton cells can take up nutrients better than large plankton cells, owing to their higher surface area to volume ratio (Morel et al. 1991, Chisholm 1992). In Sanggou Bay, phosphorus (P) was found to be deficient, whereas DIN was sufficient (Sun et al. 2007). Bivalve culture can release P into the environment (Carlsson et al. 2012, Cranford et al. 2012), and the release of $P$ by bivalves may have induced the high abundance of picoplankton in the Sanggou Bay B-area. Indeed, a $7 \mathrm{~d}$ in situ enclosure experiment in Sanggou Bay demonstrated that scallop cultivation increased the $\mathrm{PO}_{4}{ }^{3-}$ concentration, as well as the abundance of picoplankton, total nanoflagellates and ciliates (Lu et al. 2015a,b). In addition to $\mathrm{P}$ release, bivalves can excrete important amounts of ammonium ions, which also favours picophytoplankton (Chisholm 1992, Courties et al. 1994). Although we lack data on ammonium ion concentration in Sanggou Bay, it is possible that ammonium ions stimulated the growth of picoplankton in the bivalve culture area.

\section{Picoplankton biomass contribution}

In cold seasons (winter and spring), heterotrophic picoplankton carbon biomass exceeded that of autotrophic picoplankton. This result is in agreement with observations in the Sargasso Sea, where the microbial carbon biomass was dominated by nonphotosynthetic prokaryotes (Fuhrman et al. 1989, Bouvy et al. 2012). When the water temperature rose, PEUK biomass became predominant $(>50 \%)$ within the picoplankton biomass. These results differ from previous observations in distinct environments such as the northeastern Atlantic Ocean (Partensky et al. 1996), the South Pacific Ocean (Grob et al. 2007) and the Yellow Sea (Zhao et al. 2011), where SYN or HP was predominant in the picoplankton biomass. Bec et al. (2005) reported that PEUK were predominant within picoplankton, and could serve as an important carbon source for the protozoan community. Our observations are in line with these findings, support- 
ing the suggestion that PEUK could make a large contribution to the carbon flow towards higher trophic levels in coastal regions.

\section{CONCLUSION}

Our study is the first report on picoplankton seasonal abundance distribution and its variations in Sanggou Bay, China. Different distribution patterns of picoplankton abundance and biomass were observed. Physicochemical factors and protist grazing were the most important variables controlling the distribution of and variation in picoplankton abundance in Sanggou Bay. Picoplankton were more abundant in the bivalve culture area than in the macroalgae culture area, especially in warm seasons. Among the picoplankton, PEUK contributed most to the carbon biomass standing stock in summer and autumn. The reduction in protist grazing pressure, as well as P release by bivalves, are likely explanations for the higher picoplankton abundance in the bivalve culture area. In spring and winter, the heterotrophic component of the biomass exceeded that of the autotrophic picoplankton. In spring to autumn, PEUK contributed $>20 \%$ to the assessed autotrophic biomass. HP biomass amounted to $>56 \%$ of the assessed autotrophic biomass in spring, and at some stations the percentage was even larger.

Acknowledgements. This work was supported by the Natural Science Foundation of China project 41306161, 973 project 2011CB409804, and Natural Science Foundation of China project 41306160 . We are grateful to the crew members of the Rongcheng Marine Science and Technology Bureau for their assistance during the cruises.

\section{LITERATURE CITED}

Agawin NS, Duarte CM, Agusti S (2000) Nutrient and temperature control of the contribution of picoplankton to phytoplankton biomass and production. Limnol Oceanogr 45:591-600

> Agawin NS, Duarte CM, Agustí S, McManus L (2003) Abundance, biomass and growth rates of Synechococcus sp. in a tropical coastal ecosystem (Philippines, South China Sea). Estuar Coast Shelf Sci 56:493-502

> Azam F, Fenchel T, Field JG, Gray JS, Meyer-Reil LA, Thingstad F (1983) The ecological role of water-column microbes in the sea. Mar Ecol Prog Ser 10:257-263

Barillé L, Prou J, Héral M, Bourgrier S (1993) No influence of food quality, but ration-dependent retention efficiencies in the Japanese oyster Crassostrea gigas. J Exp Mar Biol Ecol 171:91-106

Bec B, Husseini-Ratrema J, Collos Y, Souchu P, Vaquer A (2005) Phytoplankton seasonal dynamics in a Mediter- ranean coastal lagoon: emphasis on the picoeukaryote community. J Plankton Res 27:881-894

Bell T, Kalff J (2001) The contribution of picophytoplankton in marine and freshwater systems of different trophic status and depth. Limnol Oceanogr 46:1243-1248

Bouvy M, Dupuy C, Pagano M, Barani A, Charpy L (2012) Do human activities affect the picoplankton structure of the Ahe atoll lagoon (Tuamotu Archipelago, French Polynesia)? Mar Pollut Bull 65:516-524

> Carlsson MS, Engström P, Lindahl O, Ljungqvist L, Petersen JK, Svanberg L, Holmer M (2012) Effects of mussel farms on the benthic nitrogen cycle on the Swedish west coast. Aquacult Environ Interact 2:177-191

- Caron DA, Lim EL, Miceli G, Waterbury JB, Valois FW (1991) Grazing and utilization of chroococcoid cyanobacteria and heterotrophic bacteria by protozoa in laboratory cultures and a coastal plankton community. Mar Ecol Prog Ser 76:205-217

Chisholm SW (1992) Phytoplankton size. In: Falkowski PG, Woodhead AD (eds) Primary productivity and biogeochemical cycles in the sea. Springer, New York, NY, p 213-237

Chisholm SW, Olson RJ, Zettler ER, Goericke R, Waterbury JB, Welschmeyer NA (1988) A novel free-living prochlorophyte abundant in the oceanic euphotic zone. Nature 334:340-343

> Courties C, Vaquer A, Troussellier M, Lautier J and others (1994) Smallest eukaryotic organism. Nature 370:255

Cranford PJ, Kamermans P, Krause G, Mazurié J and others (2012) An ecosystem-based approach and management framework for the integrated evaluation of bivalve aquaculture impacts. Aquacult Environ Interact 2:193-213

Ducklow H (2000) Bacterial production and biomass in the oceans. In: Kirchman DL (ed) Microbial ecology of the oceans. Wiley-Liss, New York, NY, p 85-120

Ducklow HW, Carlson CA (1992) Oceanic bacterial production. In: Marshall KC (ed) Advances in microbial ecology. Springer, New York, NY, p 113-181

Dupuy C, Pastoureaud A, Ryckaert M, Sauriau PG, Montanié H (2000) Impact of the oyster Crassostrea gigas on a microbial community in Atlantic coastal ponds near La Rochelle. Aquat Microb Ecol 22:227-242

> DuRand MD, Olson RJ, Chisholm SW (2001) Phytoplankton population dynamics at the Bermuda Atlantic Time-series station in the Sargasso Sea. Deep-Sea Res II 48:1983-2003

> Fournier J, Dupuy C, Bouvy M, Couraudon-Reale M and others (2012) Pearl oysters Pinctada margaritifera grazing on natural plankton in Ahe atoll lagoon (Tuamotu Archipelago, French Polynesia). Mar Pollut Bull 65:490-499

> Fuhrman JA, Sleeter TD, Carlson CA, Proctor LM (1989) Dominance of bacterial biomass in the Sargasso Sea and its ecological implications. Mar Ecol Prog Ser 57:207-217

> Gallager S, Waterbury J, Stoecker D (1994) Efficient grazing and utilization of the marine cyanobacterium Synechococcus sp. by larvae of the bivalve Mercenaria mercenaria. Mar Biol 119:251-259

Grob C, Ulloa O, Li WKW, Alarcón G, Fukasawa M, Watanabe S (2007) Picoplankton abundance and biomass across the eastern South Pacific Ocean along latitude 32.5 ${ }^{\circ}$ S. Mar Ecol Prog Ser 332:53-62

Guo X, Ford S, Zhang F (1999) Molluscan aquaculture in China. J Shellfish Res 18:19-31

$>$ Hawkins A, Fang J, Pascoe P, Zhang J, Zhang X, Zhu M (2001) Modelling short-term responsive adjustments in particle clearance rate among bivalve suspension- 
feeders: separate unimodal effects of seston volume and composition in the scallop Chlamys farreri. J Exp Mar Biol Ecol 262:61-73

> Jochem F (1988) On the distribution and importance of picocyanobacteria in a boreal inshore area (Kiel Bight, Western Baltic). J Plankton Res 10:1009-1022

> Johnson PW, Sieburth J (1979) Chroococcoid cyanobacteria in the sea: a ubiquitous and diverse phototrophic biomass. Limnol Oceanogr 24:928-935

Kamiyama T (2004) The microbial loop in a eutrophic bay and its contribution to bivalve aquaculture. Bull Fish Res Agency Jpn Suppl 1:41-50

- Kamiyama T, Yamauchi H, Iwai T, Hamasaki K (2009) Seasonal variations in abundance and biomass of picoplankton in an oyster-farming area of northern Japan. Plankton Benthos Res 4:62-71

Kimmel DG, Boynton WR, Roman MR (2012) Long-term decline in the calanoid copepod Acartia tonsa in central Chesapeake Bay, USA: an indirect effect of eutrophication? Estuar Coast Shelf Sci 101:76-85

Kreeger DA, Newell RIE (1996) Ingestion and assimilation of carbon from cellulolytic bacteria and heterotrophic flagellates by the mussels Geukensia demissa and Mytilus edulis (Bivalvia, Mollusca). Aquat Microb Ecol 11:205-214

Krempin D, Sullivan CW (1981) The seasonal abundance, vertical distribution, and relative microbial biomass of chroococcoid cyanobacteria at a station in southern California coastal waters. Can J Microbiol 27:1341-1344

Le Gall S, Hassen MB, Le Gall P (1997) Ingestion of a bacterivorous ciliate by the oyster Crassostrea gigas: protozoa as a trophic link between picoplankton and benthic suspension-feeders. Mar Ecol Prog Ser 152:301-306

> Lee S, Fuhrman JA (1987) Relationships between biovolume and biomass of naturally derived marine bacterioplankton. Appl Environ Microbiol 53:1298-1303

Li WKW (1998) Annual average abundance of heterotrophic bacteria and Synechococcus in surface ocean waters. Limnol Oceanogr 43:1746-1753

Li WKW, Dickie P (2001) Monitoring phytoplankton, bacterioplankton, and virioplankton in a coastal inlet (Bedford Basin) by flow cytometry. Cytometry 44:236-246

Li WKW, Rao S, Harrison W, Smith J, Cullen J, Irwin B, Platt $\mathrm{T}$ (1983) Autotrophic picoplankton in the tropical ocean. Science 219:292-295

Li WKW, Dickie P, Irwin B, Wood A (1992) Biomass of bacteria, cyanobacteria, prochlorophytes and photosynthetic eukaryotes in the Sargasso Sea. Deep-Sea Res A 39:501-519

Lu J, Huang L, Luo Y, Xiao T, Jiang Z, Wu L (2015a) Effects of freshwater input and mariculture (bivalves and macroalgae) on spatial distribution of nanoflagellates in Sungo Bay, China. Aquacult Environ Interact 6:191-203

Lu J, Huang L, Xiao T, Jiang Z, Zhang W (2015b) The effects of Zhikong scallop (Chlamys farreri) on the microbial food web in a phosphorus-deficient mariculture system in Sanggou Bay, China. Aquaculture 448:341-349

Marie D, Simon N, Guillou L, Partensky F, Vaulot D (2000a) DNA/RNA analysis of phytoplankton by flow cytometry. Curr Protoc Cytom 11:11.12.11-11.12.14

Marie D, Simon N, Guillou L, Partensky F, Vaulot D (2000b) Flow cytometry analysis of marine picoplankton. In: Diamond RA, DeMaggio S (eds) In living color. Protocols in flow cytometry and cell sorting. Springer, New York, NY, p 421-454

Morán XAG, Fernández E, Pérez V (2004) Size-fractionated primary production, bacterial production and net com- munity production in subtropical and tropical domains of the oligotrophic NE Atlantic in autumn. Mar Ecol Prog Ser 274:17-29

Morel FM, Hudson RJ, Price NM (1991) Limitation of productivity by trace metals in the sea. Limnol Oceanogr 36 : 1742-1755

Newell RI (2004) Ecosystem influences of natural and cultivated populations of suspension-feeding bivalve molluscs: a review. J Shellfish Res 23:51-62

Oberbeckmann S, Fuchs BM, Meiners M, Wichels A, Wiltshire KH, Gerdts G (2012) Seasonal dynamics and modeling of a Vibrio community in coastal waters of the North Sea. Microb Ecol 63:543-551

Olson RJ, Zettler ER, DuRand MD (1993) Phytoplankton analysis using flow cytometry. In: Kemp PF, Cole JJ, Sherr BF, Sherr EB (eds) Handbook of methods in aquatic microbial ecology. Lewis, Boca Raton, FL, p 175-186

Parsons T, Maita Y, Lalli C (1984) A manual of chemical and biological methods for seawater analysis. Pergamon Press, Oxford

Partensky F, Blanchot J, Lantoine F, Neveux J, Marie D (1996) Vertical structure of picophytoplankton at different trophic sites of the tropical northeastern Atlantic Ocean. Deep-Sea Res I 43:1191-1213

Riisgård HU (1988) Efficiency of particle retention and filtration rate in 6 species of Northeast American bivalves. Mar Ecol Prog Ser 45:217-223

> Sherr EB, Sherr BF (2002) Significance of predation by protists in aquatic microbial food webs. Antonie Leeuwenhoek 81:293-308

Sun P, Zhang Z, Hao L, Wang B and others (2007) Analysis of nutrient distributions and potential eutrophication in seawater of the Sangou Bay. Adv Mar Sci 25:436-455 (in Chinese with English abstract)

> Thomas Y, Courties C, El Helwe Y, Herbland A, Lemonnier $H$ (2010) Spatial and temporal extension of eutrophication associated with shrimp farm wastewater discharges in the New Caledonia lagoon. Mar Pollut Bull 61:387-398

Vaquer A, Troussellier M, Courties C, Bibent B (1996) Standing stock and dynamics of picophytoplankton in the Thau Lagoon (northwest Mediterranean coast). Limnol Oceanogr 41:1821-1828

> Waterbury JB, Watson SW, Guillard RR, Brand LE (1979) Widespread occurrence of a unicellular, marine, planktonic, cyanobacterium. Nature 277:293-294

Worden AZ, Nolan JK, Palenik B (2004) Assessing the dynamics and ecology of marine picophytoplankton: the importance of the eukaryotic component. Limnol Oceanogr 49:168-179

Yu Y, Zhang W, Jiang Z, Zhao Y, Feng M, Li H, Xiao T (2013) Seasonal variation of planktonic ciliates in Sanggou Bay, Huanghai Sea. Acta Oceanol Sin 35:215-224 (in Chinese with English abstract)

Zhang J, Hansen PK, Fang J, Wang W, Jiang Z (2009) Assessment of the local environmental impact of intensive marine shellfish and seaweed farming-application of the MOM system in the Sungo Bay, China. Aquaculture 287:304-310

Zhao Y, Zhao L, Xiao T, Zhao S, Xuan J, Li C, Ning X (2011) Spatial and temporal variation of picoplankton distribution in the Yellow Sea, China. Chin J Oceanol Limnol 29: $150-162$

Zubkov MV, Sleigh MA, Tarran GA, Burkill PH, Leakey RJ (1998) Picoplanktonic community structure on an Atlantic transect from $50^{\circ} \mathrm{N}$ to $50^{\circ} \mathrm{S}$. Deep-Sea Res I 45:1339-1355 